\title{
School nutrition guidelines: overview of the implementation and evaluation
}

\author{
Matej Gregorič ${ }^{1}$, Larisa Pograjc ${ }^{2}$, Alenka Pavlovec ${ }^{3}$, Marjan Simčič ${ }^{4}$ and \\ Mojca Gabrijelčič Blenkušl,* \\ ${ }^{1}$ National Institute of Public Health, Health Survey and Health Promotion Centre, Trubarieva 2, 1000 Liubljana, \\ Slovenia: ${ }^{2}$ Ministry of Defence of the Republic of Slovenia, Department for Military Technology, Research and \\ Development, Ljubliana, Slovenia: ${ }^{3}$ Ministry of Education, Science and Sport of the Republic of Slovenia, \\ The Pre-School and Basic Education Directorate, Ljubljana, Slovenia: ${ }^{4}$ University of Ljubljana, Biotechnical Faculty, \\ Department of Food Science and Technology, Ljubljana, Slovenia
}

Submitted 27 May 2014: Final revision received 29 October 2014: Accepted 11 December 2014: First published online 9 February 2015

\begin{abstract}
Objective: To holistically evaluate the extent of implementation of dietary guidelines in schools and present various monitoring systems.

Design: The study comprises three methods: (i) a cross-sectional survey (process evaluation); (ii) an indicator-based evaluation (menu quality); and (iii) a $5 \mathrm{~d}$ weighed food record of school lunches (output evaluation).

Setting: Slovenian primary schools.

Subjects: A total 234 food-service managers from 488 schools completed a selfadministrated questionnaire for process evaluation; 177 out of 194 randomly selected schools provided menus for menu quality evaluation; and 120 school lunches from twenty-four schools were measured and nutritionally analysed for output evaluation.

Results: The survey among food-service managers revealed high levels of implementation at almost all process evaluation areas of the guidelines. An even more successful implementation of these guidelines was found in relation to organization cultural issues as compared with technical issues. Differences found in some process evaluation areas were related to location, size and socio-economic characteristics of schools. Evaluation of school menu quality demonstrated that score values followed a normal distribution. Higher (better) nutrition scores were found in larger-sized schools and corresponding municipalities with higher socio-economic status. School lunches did not meet minimum recommendations for energy, carbohydrates or dietary fibre intake, nor for six vitamins and three (macro, micro and trace) elements.

Conclusions: The implementation of the guidelines was achieved differently at distinct levels. The presented multilevel evaluation suggests that different success in implementation might be attributed to different characteristics of individual schools. System changes might also be needed to support and improve implementation of the guidelines.
\end{abstract}

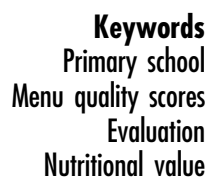

It is well known and documented that a balanced healthy diet plays an important role in the physical and cognitive development of children and adolescents, in maintaining a healthy weight and in reducing the risk of chronic diseases in the future ${ }^{(1)}$. Furthermore, healthy nutrition may have a positive impact on performance at school ${ }^{(2,3)}$.

The increasing prevalence of unhealthy diet and childhood obesity has resulted in a significant policy response from many governments followed by the implementation of school-based initiatives, including standards for school meals.
Experts agree that having access to healthy foods while being at school can enable children to develop healthy eating habits and reduce childhood obesity ${ }^{(4)}$. One common strategy to improve children's eating habits is to reduce or remove unhealthy foods from schools ${ }^{(5)}$. A universal food and nutrition policy for the European Union cannot be formulated due to the wide variation in school systems, eating habits and cultural differences in Europe ${ }^{(6)}$. The most appropriate approaches applicable to a diverse school system and health priorities were taken by different countries ${ }^{(7)}$. 
However, Slovenian children's and adolescents' dietary patterns do not differ so much from those of their counterparts in other developed countries within the European Union and wider ${ }^{(8)}$. Data indicate that Slovenian adolescents very often choose unhealthy foods, have irregular meals, skip breakfast, consume less fruit, shy away from vegetables and readily consume sugar-sweetened beverages ${ }^{(9-11)}$. Consequently, the meals of Slovenian children and adolescents are often high in added sugars, SFA and $\mathrm{Na}$. At the same time, they tend to be low in PUFA, dietary fibre, folic acid, $\mathrm{Ca}$ and vitamin $\mathrm{D}^{(12)}$. This drawback leads Slovene nutritional experts to highlight the need to improve children's and adolescents' dietary habits. Well-planned and organized healthy school meals are recognized as the most efficient and rational method of intervention to improve children's and adolescents' dietary intake ${ }^{(13)}$.

Major differences exist in the provision of school meals throughout European school systems. While some countries organize school meals for all students, in others this responsibility lies with the school ${ }^{(13)}$. Many school meal programmes have shown improvement of the immediate nutritional intake of the children ${ }^{(14-17)}$ and benefits in cognition, academic achievement and lower school absence $^{(18)}$. Further, meals provided at school constitute an important part of the children's and adolescents' diet and affect dietary habits in adults. Therefore, interventions that target healthy nutrition are needed to occur early in childhood and adolescence in order to prevent or reverse the adverse health effects of overweight and poor eating habits $^{(19)}$.

Slovenia has a long tradition of providing school meals. All Slovene schools are mandatorily involved in a well-organized and well-supported national School Meals Program, regulated by the School Meals Act ${ }^{(20)}$. School meals provide from $20 \%$ up to $70 \%$ of daily energy requirements, depending on the number of daily meals offered. According to the Act every school is obliged to organize at least one meal (mid-morning snack) for all students on an individual school day. But in practice, all primary schools offer at least one mid-morning snack and lunch to all students and the majority of them also offer breakfast and an afternoon snack for younger students. In Slovenia students enter primary school at the age of 6 years and finish it at the age of 14 years. Furthermore, mid-morning snack funding for students from low-income families is completely subsidized; and the same is true for additional school meals if the family of the student has an income below levels defined by law ${ }^{(20)}$.

The National Dietary Guidelines for Healthy Nutrition in Kindergartens and Schools ${ }^{(21)}$ (hereafter 'NDG') were adopted as part of a comprehensive Slovene Food and Nutrition Policy ${ }^{(22)}$ in 2005 and became obligatory by the renovated School Meals Act in 2010, amended in $2013^{(20)}$. Since then, schools are obliged to adapt their organization of school meals to meet these guidelines. How successfully these guidelines were introduced into routine practice can be best identified by comprehensive evaluation, such as for instance using the WHO framework with potential indicators and mechanisms for monitoring and evaluation of nutrition policies embedded in the 2006 WHO Global Strategy on Diet, Physical Activity and Health $^{(7)}$, or different other monitoring systems to evaluate school nutrition policies ${ }^{(23-25)}$.

Providing school meals that meet guidelines is very complex; therefore, it was our intention to evaluate implementation of the NDG of the School Meals Act from a holistic perspective. With this aim we employed different monitoring systems that enabled us to evaluate the implementation process and resulting outputs ${ }^{(26)}$. The purpose of the current paper is to present the evaluation approach used to assess the implementation of the NDG in Slovene primary schools during the period when these guidelines became obligatory under the Act of $2010^{(20)}$.

\section{Research design and methods}

The implementation of the NDG for healthy nutrition took place in the period 2005-2010. Due to the recognized importance of school nutrition by policy decision makers, the NDG were endorsed as a substantial part of the School Meals $\mathrm{Act}^{(20)}$ in 2010. The evaluation approach of this implementation was developed gradually during the same time period and a systematic evaluation was carried out at three different levels in the years 2010 and 2011. Taking into account the recommendations of the WHO Global Strategy on Diet, Physical Activity and Health for nutrition policy evaluation ${ }^{(7)}$, three different approaches have been developed: (i) a survey among school food-service managers for process evaluation (level 1); (ii) an indicator-based evaluation of menu quality (level 2); and (iii) nutritional assessment of school meals (level 3) for output evaluation.

Primary schools were selected from the official register of all primary schools in Slovenia, held by the Ministry of Education, Science and Sport, which served as a sampling frame for all three levels ( $n$ 448). Schools were sampled separately for each level of evaluation. All Slovene primary schools offer mid-morning snack and lunch ${ }^{(21)}$, therefore all the schools were included in the sampling procedure.

At the first level, a survey among school food-service managers was conducted from June to September 2010 with the aim to evaluate the process of implementation of the NDG. All Slovene primary schools ( $n 448)$ were invited to complete the online survey. The response rate at the first level was $52.2 \%$ ( $n$ 234).

At the second level, 194 randomly sampled primary schools were involved in indicator-based menu quality evaluation. The frequency of the indicative food items and food groups in school monthly menus was assessed and an appropriate tool was developed for this purpose. 
The menus from sampled schools were collected in May 2010 and September 2011. Menus with full details needed for evaluation of menu quality were provided by 177 (91.2\%) selected schools.

Recommended nutrient contents and energy values of 120 school lunches were analysed at the third level on a small sample of twenty-four primary schools, selected primarily for being close to the regional public health institutes due to the limited execution capacities. All selected schools allowed access to offered lunches. The nutritional quality of school lunches was assessed by measuring and analysing (calculating energy and nutrients) lunches that were offered directly to students aged 10-12 years during the period from September to December 2011. This age group was selected according to the Slovene primary-school curriculum which is organized in three triads; the middle triad, harmonized with the NDG age group of 10-12 years, was included.

The first- and second-level evaluation allowed disaggregation of the data by school location (urban and rural areas), cohesion region (eastern and western Slovenia), school size (schools divided into smaller, medium and larger, relative to the number of students) and municipality socio-economic status (schools divided into lower, medium and higher tertiles, relative to the income per capita in the school municipality). Details of the survey sample are presented in Table 1.

\section{Survey among school food-service managers}

School food-service managers were invited to complete an online survey by a circular letter. We measured the degree of implementation of the NDG with a questionnaire using a Likert scale ${ }^{(27)}$ from 1 to 5 , with 1 meaning 'not implemented' and 5 meaning 'fully implemented'. Only answers 4 and 5 were considered to meet the criteria.
The survey contained eleven evaluation questions regarding: (i) organization cultural ${ }^{(28)}$ issues including organization of school meal-planning groups and school nutrition action groups, regular inclusion of foods from quality schemes, as well as regular use of the NDG manual $^{(21)}$, the related practical manual for preparing healthy meals ${ }^{(29)}$ and the practical manual for food procurements with defined quality standards for foods ${ }^{(30)}$; and (ii) technical issues ${ }^{(21,29,30)}$ including provision of balanced mid-morning snacks, regular inclusion of foods from local production and organic production, provision of fruit and/or vegetables in each meal, and reduction of fruit and vegetable leftovers to less than $25 \%$.

\section{Indicator-based evaluation of school menu quality and definition of the nutritional score scale}

The system for evaluating menu quality was based upon the use of a food frequency checklist and food-based criteria of the inclusion of indicative foods in monthly menus. During the construction of this system ${ }^{(31)}$, data related to national epidemiological ${ }^{(32,33)}$, food consumption $^{(9,12)}$ and dietary habits ${ }^{(10,11,34)}$ were considered. Following national research data and priorities as well as information obtained from other scientific research studies $^{(35-40)}$, the classification described below was prepared as presented in Table 2.

Information regarding food frequency was recorded as the number of servings of selected food groups per month (where one month corresponds to twenty school days; for example, one serving per month $=1$, one serving per week $=4$ and one serving per day $=20$ ). The checklist covers thirty-seven indicative food items that were checked in mid-morning snacks as well as in lunches. Thus, thirtyseven food items were aggregated into nine selected food groups divided in two categories: recommended and

Table 1 Characteristics of the primary schools sampled in the present evaluation of NDG implementation, Slovenia, 2010-2011

\begin{tabular}{|c|c|c|c|c|c|c|}
\hline & \multicolumn{2}{|c|}{$\begin{array}{c}\text { Survey among school food-service } \\
\text { managers (level 1) }\end{array}$} & \multicolumn{2}{|c|}{$\begin{array}{c}\text { Indicator-based evaluation of menu } \\
\text { quality (level 2) }\end{array}$} & \multicolumn{2}{|c|}{$\begin{array}{l}\text { Nutritional values of school } \\
\text { lunches (level 3) }\end{array}$} \\
\hline & $n$ & $\%$ & $n$ & $\%$ & $n$ & $\%$ \\
\hline \multicolumn{7}{|l|}{ School location } \\
\hline Rural & 146 & $62 \cdot 4$ & 107 & 60.5 & 10 & $41 \cdot 7$ \\
\hline Urban & 88 & $37 \cdot 6$ & 70 & 39.5 & 14 & $58 \cdot 3$ \\
\hline \multicolumn{7}{|l|}{ Cohesion region } \\
\hline Eastern Slovenia & 144 & $61 \cdot 5$ & 100 & $56 \cdot 5$ & 12 & $50 \cdot 0$ \\
\hline Western Slovenia & 90 & 38.5 & 77 & 43.5 & 12 & $50 \cdot 0$ \\
\hline \multicolumn{7}{|l|}{ School size† } \\
\hline Small & 78 & $33 \cdot 3$ & 52 & $29 \cdot 4$ & 3 & $12 \cdot 5$ \\
\hline Medium & 78 & $33 \cdot 3$ & 69 & $39 \cdot 0$ & 10 & $41 \cdot 7$ \\
\hline Large & 78 & $33 \cdot 3$ & 56 & $31 \cdot 6$ & 11 & $45 \cdot 8$ \\
\hline \multicolumn{7}{|c|}{ Socio-economic status of municipality† } \\
\hline Low & 78 & $33 \cdot 3$ & 51 & $28 \cdot 8$ & 3 & $12 \cdot 5$ \\
\hline Medium & 78 & $33 \cdot 3$ & 61 & 34.5 & 10 & 41.7 \\
\hline High & 78 & $33 \cdot 3$ & 65 & $36 \cdot 7$ & 11 & $45 \cdot 8$ \\
\hline
\end{tabular}

NDG, National Dietary Guidelines for Healthy Nutrition in Kindergartens and Schools ${ }^{(21)}$.

†Tertile cut-offs were used to classify schools as we do not have clear definitions of school size and graduation of socio-economic status of municipalities in Slovenia. The distribution of schools into three groups for the first level of evaluation was also used for the second and third level of evaluation ${ }^{(33)}$. 
Table 2 Components and assessment of menu quality scores used in the present evaluation of NDG implementation, Slovenia, 2010-2011

\begin{tabular}{|c|c|c|}
\hline $\begin{array}{l}\text { Food groups and recommended } \\
\text { frequency per month, as } \%^{(21,31)}\end{array}$ & Food items included in score system & Allocation of points ${ }^{(35)}$ \\
\hline \multicolumn{3}{|l|}{ Recommended food groups } \\
\hline Vegetable and/or fruit (100\%) & $\begin{array}{l}\text { Cooked vegetables; preserved vegetables; salad/ } \\
\text { raw vegetables; fresh fruit; preserved fruit }\end{array}$ & \multirow{4}{*}{$\begin{array}{l}F / R \leq 1, \text { proportional points up to } 100 \\
F / R>1,100 \text { points }\end{array}$} \\
\hline Wholegrain products ( $>50 \%)$ & $\begin{array}{l}\text { Wholegrain bread; wholegrain pasta; wholegrain } \\
\text { rice; wholegrain products; cereals; porridge; } \\
\text { flakes }\end{array}$ & \\
\hline $\begin{array}{l}\text { Recommended meat }(>40 \%) \\
\text { Fish and fish products }(>30 \%)\end{array}$ & $\begin{array}{l}\text { Poultry; low-fat meat with visible structure } \\
\text { Fish: fish products: canned fish }\end{array}$ & \\
\hline $\begin{array}{l}\text { Recommended beverages } \\
(100 \%)\end{array}$ & Tap water; mineral water; fruit/herbal tea; fruit juices & \\
\hline \multicolumn{3}{|l|}{ Non-recommended food groups } \\
\hline $\begin{array}{l}\text { Bakery and confectionery } \\
\text { products }(<10 \%)\end{array}$ & Cakes/sweet pastry; sweet biscuits; sweet deserts & \multirow{4}{*}{$\begin{array}{l}F / R \leq 1,100 \text { points } \\
F / R>1 \text { and } \leq 3, \text { points } \\
\text { proportionally subtracted from } 100 \\
F / R>3,0 \text { points }\end{array}$} \\
\hline Processed meat $(<10 \%)$ & $\begin{array}{l}\text { Sausage/bacon; 'fast food' meat; meatloaf; salami } \\
\text { with homogeneous content; meat spreads }\end{array}$ & \\
\hline $\begin{array}{l}\text { Sugar-sweetened beverages } \\
(<10 \%)\end{array}$ & Soft drinks; ice tea; energy drinks; fruit syrup drinks & \\
\hline Deep fried foods $(<10 \%)$ & $\begin{array}{l}\text { Fried potatoes/chips; fried meat; fried cheese; other } \\
\text { deep fried foods }\end{array}$ & \\
\hline
\end{tabular}

NDG, National Dietary Guidelines for Healthy Nutrition in Kindergartens and Schools ${ }^{(21)} ; F / R$, frequency $(F) /$ recommended frequency $(R)$ ratio for the food group.

non-recommended, as they are defined by the $\mathrm{NDG}^{(21)}$. In the case of monitoring two offered menus at the same time, data related to frequency were expressed as an average of these two meals. Information regarding the frequency of indicative foods was compared with foodbased criteria for healthy school meals ${ }^{(21,31)}$, as seen in Table 2.

Because our scoring approach has not yet been validated, for the purpose of the present paper score calculations and allocation of points follow the concept developed by a group from the Robert Koch Institute (Berlin, Germany) ${ }^{(35)}$ as described below. Every food group was related back to the recommendations by calculating the ratio for food group $x$ :

$$
\text { Ratio }_{x}=\left(\frac{F}{R}\right)_{x}
$$

where $F$ is frequency of food group $x$ and $R$ is recommended frequency for food group $x$.

Then, the ratio $(F / R)_{x}$ was allocated with points relating to the percentage of the recommended frequency for a single food group $\left((F / R)_{x} \rightarrow\right.$ score $\left._{x}\right)$. All results below/over the recommendations were assessed proportionally ${ }^{(35)}$.

For recommended food groups, 100 points were given for each group if the menu reached or exceeded the recommended frequency. Points were proportionally subtracted from 100 if the menu did not reach the recommended frequency. If the frequency of nonrecommended food groups was below or equal to a tolerable frequency, 100 points were given. If it exceeded the recommendation, points were proportionally subtracted from 100, since frequencies above the recommendation level for these foods are considered unfavourable. Finally, single points were added together and standardized in a scale from 0 to $100^{(35)}$, as follows:

$$
\text { Menu quality score }=\left(\frac{\sum \text { score }_{x}}{N_{\text {score }_{x}}}\right),
$$

where $N_{\text {score }}$ is the number of score components/food groups included.

\section{Nutritional values of school lunches, estimated by weighed food records}

School lunches offered to students in primary schools were evaluated for compliance with the NDG that included school meal recommendations for energy, macronutrients, dietary fibre, vitamins, and macro, micro and trace elements ${ }^{(21)}$. Dietary recommendations for school meals were based on D-A-CH (D-German, A-Austrian, $\mathrm{CH}-\mathrm{Sw}$ wss) Reference Values for Nutrient Intake, which have been adopted and used as officially recognized values for Slovenia since $2004^{(41)}$ (Tables 5 and 6).

To estimate the nutritional values of school lunches, a $5 \mathrm{~d}$ weighed food record method was used ${ }^{(42-44)}$. At each school three randomly selected lunches were monitored on the monitoring day. Lunches were taken away immediately after the pupil received them. After that lunches were weighted using professional scales (type Scale House NCS3K; Dini Argeo SRL, Spezzano di Fiorano, Italy) to the nearest $0 \cdot 1 \mathrm{~g}$. Each food item or dish was weighed with the container and a standard container mass was subtracted from the total mass. Disassembling of composite dishes was made before weighing where appropriate. The weight of pre-packaged food items was recorded as it was indicated on the package. For each lunch a recipe 
was obtained that contained information on the quantities of raw food items, preparation procedure and yields/ retention factors ${ }^{(45)}$. The process of monitoring school meals was performed by nutritional experts from regional public health institutes, using pre-prepared methodological instructions.

Average nutritional values of lunches for each school were calculated by the National Institute of Public Health, using the OPEN nutrition data software system (Jožef Stefan Institute, Ljubljana, Slovenia) ${ }^{(46)}$. The structure and use of OPEN software have been described in detail elsewhere ${ }^{(46,47)}$.

\section{Statistical analysis}

Data obtained from the survey among school food-service managers and the indicator-based evaluation of menu quality were analysed across characteristics of school location, cohesion region, school size and socio-economic status. Data for the third evaluation level were not analysed across characteristics due to the small sample size.

Results were analysed statistically using the statistical software package IBM SPSS Statistics $17 \cdot 0^{(48)}$. The $\chi^{2}$ test was used to compare proportions between two or more categories and the ANOVA test was used to identify differences among group means. The school lunches were analysed using a one-sample $t$ test to compare the means of energy and nutrient values of school meals against the national recommendations as the specified constant. The level of statistical significance was set to $P<0 \cdot 05$.

\section{Results}

\section{Survey among school food-service managers}

The survey results indicated high levels of implementation regarding almost all evaluation areas of the NDG. In general, all schools reported regular use of the NDG manual at their daily work but were less successful in the case of organizing meal-planning groups and of including foods from organic production. Schools were slightly more successful in the implementation of the NDG in relation to organization cultural issues than in relation to the technical issues (Table 3).

All evaluation areas were also examined across characteristics of location, cohesion region, school size and socio-economic status of the municipality, and the results are presented in Table 3. Smaller schools as well as rural schools, which are in general of smaller size, were more successful at implementing the NDG in relation to organizational matters and less successful at providing and including healthier foods. Furthermore, schools from municipalities with lower socio-economic status reported a more successful implementation of the NDG at organizational level.

\section{Indicator-based evaluation of school menu quality}

Values of nutritional scores for school menu quality followed a normal distribution. The overall average of the

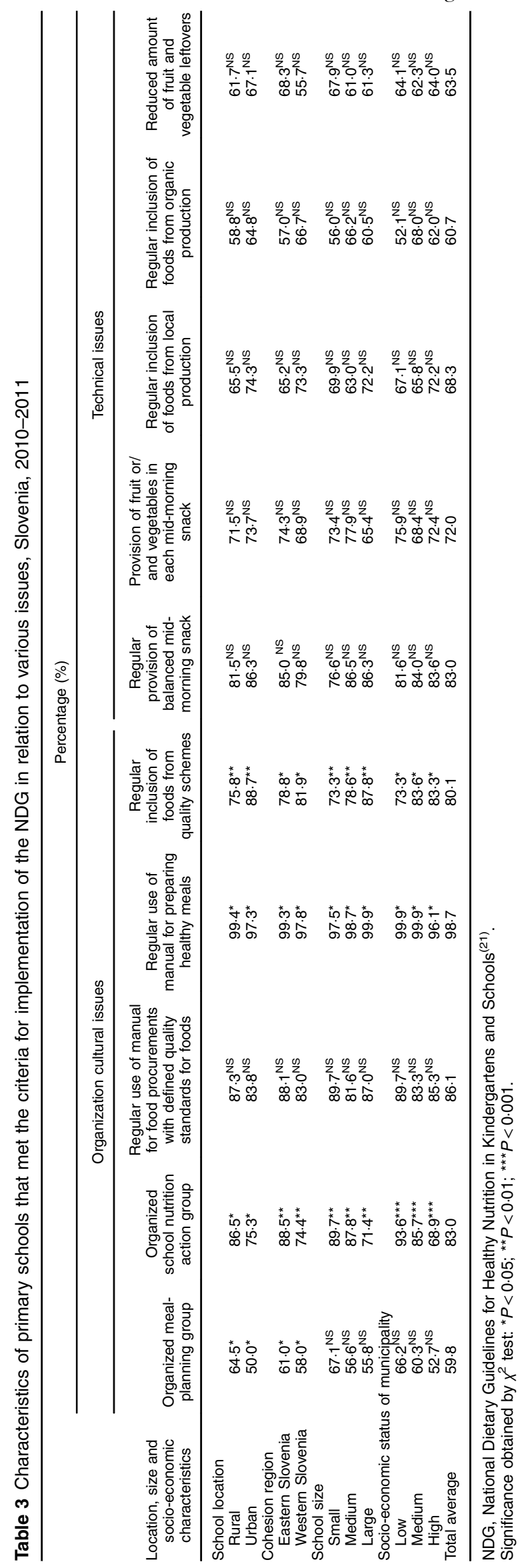


scores was 61.6 with a minimum of 36.4 and a maximum of 81.7 points. The interquartile range extended from 55.9 to $68 \cdot 2$. Table 4 shows the crude average values of scores by various location, size and socio-economic characteristics. A statistically significant higher (better) average score was detected in larger schools with a higher number of students and to some extent among schools belonging to municipalities with a higher socio-economic status.

\section{Nutritional values of school lunches}

School lunches on average contained adequate amounts of protein and did not significantly exceed the maximum recommended values for sugars, total fat and SFA. On the other hand, school lunches contained significantly less energy, carbohydrates and dietary fibre than minimum recommended values (Table 5) and consequently students covered on average only $25 \cdot 2 \%$ instead of $35-40 \%$ of their daily energy requirements with school lunches ${ }^{(21)}$.

According to the percentage of contained energy, school lunches provided students with an average of $18.0 \%$ of energy from protein, $31.4 \%$ from total fat $(7.6 \%$ from SFA) and 50.6\% from carbohydrates (10.8\% from sugars).

Table 4 Menu quality scores in relation to various location, size and socio-economic characteristics of primary schools, Slovenia, 2010-2011

\begin{tabular}{llll}
\hline Characteristic & Mean & $95 \% \mathrm{Cl}$ & SD \\
\hline School location & & & \\
$\quad$ Rural & $61 \cdot 7^{\mathrm{NS}}$ & $60 \cdot 0,63 \cdot 4$ & $8 \cdot 8$ \\
$\quad$ Urban & $61 \cdot 4^{\mathrm{NS}}$ & $59 \cdot 3,63 \cdot 5$ & $8 \cdot 7$ \\
Cohesion region & & & \\
$\quad$ Eastern Slovenia & $60 \cdot 7^{\mathrm{NS}}$ & $58 \cdot 9,62 \cdot 4$ & $8 \cdot 7$ \\
$\quad$ Western Slovenia & $62 \cdot 7^{\mathrm{NS}}$ & $60 \cdot 7,67 \cdot 7$ & $8 \cdot 8$ \\
School size & & & \\
Small & $59 \cdot 5^{\star *}$ & $56 \cdot 7,62 \cdot 3$ & $9 \cdot 9$ \\
Medium & $60 \cdot 9^{\star *}$ & $59 \cdot 0,62 \cdot 8$ & $7 \cdot 9$ \\
$\quad$ Large & $64 \cdot 2^{* *}$ & $62 \cdot 1,66 \cdot 4$ & $8 \cdot 1$ \\
Socio-economic status of municipality & & \\
$\quad$ Low & $61 \cdot 5^{*}$ & $59 \cdot 7,63 \cdot 5$ & $9 \cdot 9$ \\
Medium & $59 \cdot 9^{*}$ & $57 \cdot 7,62 \cdot 2$ & $7 \cdot 9$ \\
High & $63 \cdot 6^{*}$ & $61 \cdot 3,65 \cdot 6$ & $8 \cdot 1$ \\
\hline
\end{tabular}

Significance obtained by ANOVA test: ${ }^{*} P<0.05$; ${ }^{\star \star} P<0.01$; ${ }^{\star \star \star} P<0.001$.
In addition, school lunches were examined and compared with the dietary recommendations for vitamins, and macro, micro and trace elements. School lunches contained significantly less retinol, vitamin D, riboflavin, pantothenic acid, biotin and folic acid than the recommended levels. Values of vitamin $\mathrm{B}_{6}$ significantly exceeded the recommended levels (Table 6).

Regarding macro, micro and trace elements, school lunches significantly exceed the recommended levels of $\mathrm{Na}, \mathrm{Cl}^{-}, \mathrm{K}$ and Se. The levels of $\mathrm{Ca}, \mathrm{P}$ and $\mathrm{Fe}$ were significantly lower than recommended amount (Table 6).

\section{Discussion}

Regulation of school meals in Slovenia is strongly supported with national legislation. With this regulation, the State enables students to make healthy nutritional choices, develop healthy nutritional habits ${ }^{(20)}$ and consequently reduces social inequalities and effectively responds to high employment levels of women in Slovenia ${ }^{(33)}$. The Slovene School Meals Program is focused on providing healthy meals, which should comply with the NDG ${ }^{(21)}$ regarding the frequency of food groups included, as well as recommended energy and nutritional values. In addition, the NDG also provide a list of non-recommended foods for school meals. Undesirable foods can be included in school meals only in low frequency and low amounts. Defined by the law, the School Meals Program is - in addition to providing the availability of high-quality school meals - also aimed at learning healthy habits; raising awareness about sustainable consumption, optimal growth and cognitive development; and developing responsible attitudes towards health and the environment $^{(20)}$.

Reviews of school nutrition interventions in other countries indicate that most of them are oriented either to healthy nutrition education ${ }^{(49-51)}$ or other interventions such as school lunches, school canteens ${ }^{(52,53)}$, vending machines ${ }^{(54)}$, or specific practices such as school breakfast programmes ${ }^{(55,56)}$ and school gardens ${ }^{(57)}$. Some interventions tend to focus only on specific foods, such as the School Fruit Scheme ${ }^{(58-60)}$, or specific dietary outcomes, such as decreased consumption of

Table 5 Recommended and mean daily values of energy, macronutrients and dietary fibre in lunch offered to students aged 10-12 years, Slovenia, 2010-2011

\begin{tabular}{|c|c|c|c|c|c|c|c|}
\hline & \multirow[b]{2}{*}{ Recommended value } & \multicolumn{6}{|c|}{ Estimated lunch values } \\
\hline & & Mean & Mean difference & $95 \% \mathrm{Cl}$ & $\mathrm{SD}$ & $t$ & Significance (two-tailed) \\
\hline Energy (kJ) & $206 \cdot 1$ & $138 \cdot 3$ & -67.8 & $55 \cdot 5,80 \cdot 2$ & $29 \cdot 2$ & $11 \cdot 3$ & $\star \star \star$ \\
\hline Protein (g) & $26 \cdot 3$ & $26 \cdot 3$ & 0.0 & $3 \cdot 1,3 \cdot 2$ & $7 \cdot 5$ & 0.0 & NS \\
\hline Total fat (g) & $<29.3 \dagger$ & $19 \cdot 8$ & -9.5 & $7 \cdot 1,11.9$ & $5 \cdot 6$ & $8 \cdot 3$ & $\star * *$ \\
\hline SFA $(g)$ & $<9.8$ & 4.9 & $-4 \cdot 8$ & $4 \cdot 1,5 \cdot 6$ & 1.7 & $14 \cdot 2$ & $\star \star \star *$ \\
\hline Carbohydrates (g) & $>105 \cdot 8$ & $72 \cdot 2$ & -33.5 & $25 \cdot 6,41 \cdot 4$ & $18 \cdot 8$ & 8.7 & $\star * *$ \\
\hline Sugars $(g)$ & $<21.0$ & $15 \cdot 8$ & $-5 \cdot 2$ & $1.9,8.4$ & $7 \cdot 6$ & $3 \cdot 3$ & $\star \star$ \\
\hline Dietary fibre (g) & $>8.6$ & 7.6 & -1.0 & $0.1,1.8$ & 1.9 & 2.5 & * \\
\hline
\end{tabular}

Significance obtained by $t$ test: ${ }^{\star} P<0.05 ;{ }^{\star \star} P<0.01 ;{ }^{* \star} P<0.001$.

†Based on less than $30 \%$ of energy from fat. 
Table 6 Recommended and mean daily values of vitamins, macro, micro and trace elements in lunch offered to students aged 10-12 years, Slovenia, 2010-2011

\begin{tabular}{|c|c|c|c|c|c|c|c|}
\hline & \multirow[b]{2}{*}{ Recommended value } & \multicolumn{6}{|c|}{ Estimated lunch values } \\
\hline & & Mean & Mean difference & $95 \% \mathrm{Cl}$ & SD & $t$ & Significance (two-tailed) \\
\hline \multicolumn{8}{|l|}{ Vitamins } \\
\hline Biotin $(\mu \mathrm{g})$ & 9.5 & $6 \cdot 1$ & -3.4 & $2 \cdot 4,4.5$ & 2.5 & $6 \cdot 8$ & $\star \star \star \star ~$ \\
\hline Folic acid $(\mu \mathrm{g})$ & 150 & 99.9 & $-50 \cdot 1$ & $37 \cdot 7,62 \cdot 5$ & 29.4 & $8 \cdot 3$ & $\star \star \star *$ \\
\hline Niacin $(\mu \mathrm{g})$ & 5250 & 5314.5 & +64.5 & $650 \cdot 8,780 \cdot 0$ & 1694.2 & 0.2 & NS \\
\hline Pantothenic acid (mg) & 1.9 & 1.4 & -0.5 & $0.2,0.6$ & 0.4 & 4.8 & 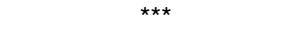 \\
\hline Retinol $(\mu \mathrm{g})$ & 337.5 & $182 \cdot 0$ & -155.5 & $80 \cdot 0,230 \cdot 9$ & $178 \cdot 7$ & $4 \cdot 3$ & $\star \star \star *$ \\
\hline Riboflavin (mg) & 0.5 & 0.3 & -0.2 & $0.1,0.2$ & 0.1 & $7 \cdot 0$ & $\star \star \star \star ~$ \\
\hline Thiamin (mg) & 0.4 & 0.4 & 0.0 & $0.1,0.1$ & $0 \cdot 1$ & 0.1 & NS \\
\hline Vitamin $B_{12}(\mu \mathrm{g})$ & 0.7 & 0.9 & $+0 \cdot 2$ & $0.2,0.5$ & 0.9 & 0.8 & NS \\
\hline Vitamin $B_{6}(\mathrm{mg})$ & 0.4 & 0.6 & +0.2 & $0.1,0.3$ & 0.2 & $5 \cdot 1$ & 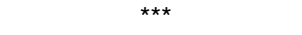 \\
\hline Vitamin C (mg) & $33 \cdot 8$ & $39 \cdot 1$ & $+5 \cdot 3$ & $2 \cdot 7,13 \cdot 3$ & $19 \cdot 0$ & 1.4 & NS \\
\hline Vitamin D $(\mu \mathrm{g})$ & 1.9 & 0.5 & $-1 \cdot 4$ & $1 \cdot 1,1 \cdot 6$ & 0.6 & $11 \cdot 2$ & $\star \star \star \star ~$ \\
\hline Vitamin E (mg) & 4.5 & $5 \cdot 0$ & +0.5 & $0.5,1.4$ & $2 \cdot 2$ & $1 \cdot 1$ & NS \\
\hline \multicolumn{8}{|l|}{ Macro elements } \\
\hline $\mathrm{Ca}(\mathrm{mg})$ & $412 \cdot 5$ & 151.5 & $-261 \cdot 0$ & $234 \cdot 7,287 \cdot 2$ & $62 \cdot 2$ & $20 \cdot 6$ & $\star \star \star \star ~$ \\
\hline $\mathrm{Mg}(\mathrm{mg})$ & 90 & 85.4 & $-4 \cdot 6$ & $4 \cdot 9,14 \cdot 2$ & $22 \cdot 6$ & 1.0 & NS \\
\hline$P(\mathrm{mg})$ & $468 \cdot 8$ & $330 \cdot 1$ & $-138 \cdot 7$ & $103 \cdot 2,174 \cdot 2$ & 84.0 & $8 \cdot 1$ & $\star \star \star \star ~$ \\
\hline $\mathrm{K}(\mathrm{mg})$ & 637.5 & $1001 \cdot 3$ & +363.8 & $249 \cdot 6,478 \cdot 1$ & $270 \cdot 6$ & $6 \cdot 6$ & $\star \star \star *$ \\
\hline $\mathrm{Na}(\mathrm{mg})$ & 191.3 & $1349 \cdot 9$ & $+1158 \cdot 6$ & $998.3,1318.9$ & 379.7 & $15 \cdot 0$ & $\star \star \star \star ~$ \\
\hline $\mathrm{Cl}^{-}(\mathrm{mg})$ & 288.8 & $2102 \cdot 1$ & $+1813 \cdot 3$ & $1564 \cdot 1,2062 \cdot 5$ & $590 \cdot 2$ & $15 \cdot 1$ & $\star \star \star \star ~$ \\
\hline \multicolumn{8}{|l|}{ Micro and trace elements } \\
\hline $\mathrm{Fe}(\mathrm{mg})$ & $5 \cdot 1$ & $3 \cdot 8$ & $-1 \cdot 3$ & $0.7,1.9$ & 1.3 & $4 \cdot 8$ & $\star \star \star \star ~$ \\
\hline lodine $(\mu \mathrm{g})$ & 67.5 & 63.4 & $-4 \cdot 1$ & $4 \cdot 6,12 \cdot 8$ & 20.5 & 1.0 & NS \\
\hline $\mathrm{Zn}(\mathrm{mg})$ & 3 & 2.9 & -0.1 & $0.4,0.5$ & 1.1 & 0.2 & NS \\
\hline Se $(\mu g)$ & $16 \cdot 4$ & $24 \cdot 4$ & $+8 \cdot 0$ & $0 \cdot 1,16 \cdot 0$ & $18 \cdot 8$ & $2 \cdot 1$ & * \\
\hline
\end{tabular}

Significance obtained by $t$ test: ${ }^{*} P<0.05 ;{ }^{* *} P<0.01 ;{ }^{* \star *} P<0.001$.

high-fat choices ${ }^{(61)}$ and sugar-sweetened beverages ${ }^{(62)}$. However, only a state-wide nutrition policy that targets all foods and beverages and school environments may be effective; otherwise, compensation of dietary outcomes may occur ${ }^{(63)}$.

The overview of the implementation of the NDG at different evaluation levels presented herein revealed that expected changes in organization and offer of school meals, resulting from interventions, are not equally effective in meeting these guidelines. As will be discussed below, the level 1 process evaluation showed very good results, but at the same time a more specific, in-depth evaluation of the quality of meals offered pinpointed important reservations and challenges for future implementation.

The overview showed evidence that some school characteristics such as size, location and socio-economic environment can play an important role in implementation procedures. We observed that the results of the survey among Slovene school food-service managers indicated high levels of implementation at almost all observed level 1 evaluation areas, which is in agreement with other studies that evaluated the process of the implementation of nutrition initiatives in schools ${ }^{(15,64)}$. In Slovenia's case, providing quality school meals is a high priority for all schools ${ }^{(31)}$. We can explain this with the fact that, characteristically for Slovenia, organized school meals are quite often cheaper than the food prepared at home ${ }^{(65)}$ and also suit well the mostly employed Slovene mothers ${ }^{(33)}$. Furthermore, the School Meals Program is a part of nutrition education, as parts of formal and hidden curricula $^{(20)}$. This means that healthy diet is supported with the curriculum topics, where children receive important information on healthy eating practices in home economics classes as part of the average curriculum ${ }^{(33)}$.

Greater focus and implementation support was found to be required in the areas of operationalization of mealplanning groups; reduction of fruit and vegetable leftovers; and regular inclusion of foods from organic and local production. This might be explained by problems surrounding public procurement of foods and food prices ${ }^{(31)}$ about which schools often have reported. Low quantities of locally produced or organic foods and complicated legislation on public procurement can be an inhibiting factor. In addition, a lack of involvement on behalf of students, school management, parents and public health representatives in school nutrition groups, as well as a lack of knowledge, organizational skills or awareness, are all elements which might be attributed to the traditional organizational culture at an individual school with important potential for improvement. More successful implementation of the NDG in rural schools, as related to organizational matters, might be attributed to more personal relationships in smaller schools. But on the contrary, these schools had more difficulties to provide and include healthier foods, which are more often more expensive for them. Higher prices and limited availability of healthier 
foods in smaller, rural and more distant communities have been documented in other studies ${ }^{(66)}$. It is also not unusual that food-service managers at smaller schools perform other duties besides managing food service such as teaching - and might therefore not be as dedicated as their colleagues in larger schools whose only job is the management of food service ${ }^{(65)}$. Schools from the eastern part of Slovenia were more successful in implementing establishment of meal-planning groups. School nutrition action groups and the use of manuals for preparing healthy meals, which might be attributable to different cultural habits, influenced organizational culture at the school level, while schools from (in general) the wealthier western side of Slovenia ${ }^{(33)}$ were more successful at providing more quality foods. Schools from municipalities with a medium socio-economic status compared with those with lower and higher socio-economic status seemed to have fewer problems implementing the NDG in terms of inclusion of foods from high-quality schemes. These reported differences in implementation may be explained by various support levels available from different regional institutions and distinct financial capacities at the school level. All of the differences described above might to some extent be explained also by contrasting levels of interest and abilities among individuals responsible for implementing the NDG.

The indicator-based systems offer a valuable instrument to evaluate overall menu quality in schools. They can be used as a simple, low-cost indicative tool to detect schools with undesirable foods included in school meals. The results of the currently applied indicator-based evaluation menu score system ${ }^{(35)}$ are consistent with the findings of the Slovene School Meals Program evaluation report from $2012^{(45)}$, where weighted scores were used ${ }^{(31)}$. Both approaches revealed that schools with lower scoring results provided school menus that on average did not include enough recommended food groups - particularly fish and wholegrain products - and exceed maximum recommended frequency for sugar-sweetened bakery and confectionery products, as well as sugar-sweetened beverages.

Taking into consideration school size and the socioeconomic status of a municipality, differences in score values were statistically significant: better menu quality was related to larger schools and higher socio-economic status of the municipality. Furthermore, insignificant differences among school location and cohesion region groups may be the result of a long tradition of reducing inequalities among regions through a variety of schoolbased programmes and interventions ${ }^{(33)}$. On the other hand, relatively important differences among score values were detected among individual schools where additional efforts for improvement are necessary. These differences in menu quality were also detected in the Slovene School Meals Program 2010 evaluation ${ }^{(31)}$.

Nutritional score systems, composed of relevant indicative indices, are designed to capture 'healthy menus' and to reflect compliance with the recommendations. Moreover, the construction of nutritional scores appears to be useful for several reasons ${ }^{(67)}$. The scoring system is used to summarize the abundance of information on individual food items into a single indicator for an overall impression of menu quality. Index approaches are subjective and limited by current knowledge, selection of components, assessment methods and available information ${ }^{(67)}$. A decision for using different weights in scorings is also subjective and a matter of further validation studies.

The relatively low energy content of the average school lunch might be explained by excessive levels of energy in subsidized school mid-morning snacks, which exceeded the recommended values ${ }^{(68)}$; leading to the fact that the joint energy intake of mid-morning snacks and lunches was close to the recommended one. Smaller portion sizes and lower energy density can affect the energy value of meals ${ }^{(69)}$, which was recognized as a possible reason for the lower energy content of school lunches ${ }^{(45)}$. School lunches did have low carbohydrate and fat contents, and consecutively lower energy values. Similarly, the relatively low nutritional quality of school lunches might reflect the frequent inclusion of low-nutrient-dense foods, the low inclusion of milk and milk products in menus, as well as the lack of vegetables in lunches ${ }^{(45)}$. Low Ca and vitamin D intakes are well documented among children and adolescents $^{(70,71)}$. The inadequate quality of school lunches is perhaps surprising but not unusual, taking into consideration that children and adolescents are the population group most likely to have a higher risk of nutritional deficiencies ${ }^{(71)}$. Similar results were found in English schools, where the majority of children did not meet the recommendations for lunch nutrient intake, especially for micronutrients ${ }^{(72)}$. The very high levels of $\mathrm{Na}$ are of significant concern and likely reflect the frequent inclusion of processed foods (pre-treated foods, semifinished products, instant soups and sauces, etc. $)^{(45)}$. The interpretation of the results could be related to the method used $^{(73)}$. In our study we used food composition data to estimate the nutritional quality of lunches. Comparison of these data with analytical ones, which we did not have, would be more accurate and easier to explain. Methods of measuring food intake are not standardized across Europe $^{(73)}$. However, it is evident that more nutritional education with a focus on menu design should be oriented towards food-service managers in the future ${ }^{(45)}$.

As we have discussed above, only multilevel evaluation of programme implementation can give public health professionals a clear insight into the implementation results and provide tangible and useful results for policy makers and policy decisions for future implementation improvements. Such types of evaluation overview as the one presented here are essential to ensure well-informed public policy decisions ${ }^{(74)}$. The power of knowledge is one of the crucial political forces for moving health issues on to policy agendas in general ${ }^{(75)}$ and implementing 
them. Different approaches of transferring knowledge to policy and practice are under development ${ }^{(76)}$ and public health nutrition areas should incorporate these new methodological developments, too.

The present overview provided evidence that use of multilevel evaluation approaches appears to be useful for several reasons. In general, the evaluation overview has demonstrated that nutrition interventions in schools are implemented differently at distinct levels.

The present study demonstrates that although schools believe that they are making positive changes to adolescents' diets, in fact the School Meal Program is reaching the food-based dietary guidelines and nutrient recommendations only to some extent. The evaluation overview suggests that specific barriers at different levels require different measures to improve the implementation of the NDG. Specific important school-based dietary recommendations for school food-service managers include placing more emphasis on the importance of food-based criteria for the composition of healthy school meals. The Slovenian National Institute of Public Health intends to validate the indicator-based evaluation of menu quality with the aim to provide stronger evidence-based arguments for future implementation steps. However, all primary schools in Slovenia should use standardized recipes to ensure that their menus meet the specific standards of a healthy school diet. A clear set of rules and instructions regulating the work of school kitchen personnel should be adopted. In the institutionalized School Meal Program no substantial differences should appear in the quality of school meals among schools varying in size, location, cohesion region and socio-economic status of the municipality.

The guidelines alone do not result in the required changes in practice. The implementation of guidelines in complex systems such as school nutrition programmes might require different system changes, the evaluation at different levels and the use of alternative research designs. This should be considered not only by researchers, but also by school policy makers, who are interested in improving students' nutritional intake, performance at school and consequently their future health.

\section{Acknowledgements}

Acknowledgements: The authors acknowledge and thank Franc Jesenek, Mojca Vivoda, Mateja Šturm, Rok Poličnik, Barbara Gregorič Gorenc, Branka Đukić, Anja Magajna, Lilijana Spasojevič, Cecilija Sušec, Gordana Toth, Irena Jerič, Brigita Zupančič Tisovec and Tea Kordiš for their assistance in checking menus and monitoring school lunches. Many thanks also go to Dr Katja Povhe Jemec and Rok Poličnik for their critical review of the study, and to Darja Lavtar for her methodological assistance. Last but not least, the authors are grateful to all participating schools.
Financial support: This study was supported by the Ministry of Health of the Republic of Slovenia and the Ministry of Education, Science and Sport of the Republic of Slovenia. Neither Ministry had a role in the design, analysis or writing of this article. Conflict of interest: None. Authorship: M.G. contributed to the conception and design of the study, the acquisition of national survey, menu quality and weighed food record data, the analysis and interpretation of data, the drafting of the article and final approval of the version to be published. L.P. revised the article critically for important intellectual content and gave final approval of the version to be published. A.P. and M.S. contributed to the conception and design of the food consumption study, revised the article critically for important intellectual content and gave final approval of the version to be published. M.G.B. contributed to the conception and design of the evaluation study, the description of the methodology, the interpretation of data, revised the article critically for important intellectual content and gave final approval of the version to be published. Ethics of buman subject participation: The study was conducted according to the guidelines laid down in the Declaration of Helsinki for all procedures involving human subjects.

\section{References}

1. Waxman A (2003) Prevention of chronic diseases: WHO global strategy on diet, physical activity and health. Food Nutr Bull 24, 281-284

2. Bellisle F (2004) Effects of diet on behaviour and cognition in children. BrJ Nutr $\mathbf{9 2}, 227-232$.

3. Taras H (2005) Nutrition and student performance at school. J Sch Health 75, 199-213.

4. World Health Organization (2008) School Policy Framework: Implementation of the WHO Global Strategy on Diet, Physical Activity and Health. Geneva: WHO.

5. Vecchiarelli S, Takayanagi S \& Neumann C (2006) Students' perceptions of the impact of nutrition policies on dietary behaviours. J Sch Health 76, 540-542.

6. PHEIAC Public Health Evaluation and Impact Assessment Consortium (2013) Evaluation of the implementation of the Strategy for Europe on Nutrition, Overweight and Obesity related health issues, Final report. Brussels: European Commission, Directorate General Health \& Consumers; available at http://ec.europa.eu/health/nutrition_physical_ activity/docs/pheiac_nutrition_strategy_evaluation_en.pdf

7. World Health Organization (2008) WHO Global Strategy on Diet, Physical Activity and Health: A Framework to Monitor and Evaluate Implementation. Geneva: WHO; available at http://www.who.int/dietphysicalactivity/M\&E-ENG-09.pdf

8. Currie C, Zanotti C, Morgan A et al., editors (2012) Social Determinants of Health and Well-Being Among Young People. Health Behaviour in School-aged Children (HBSC) Study: International Report from the 2009/2010 Survey. Copenhagen: WHO Regional Office for Europe.

9. Kobe H, Štimec M, Hlastan Ribič C et al. (2012) Food intake in Slovenian adolescents and adherence to the optimized mixed diet: a nationally representative study. Public Health Nutr 15, 600-608.

10. Gregorič M \& Koch V (2007) Prehranska kakovost zajtrka slovenskih srednješolcev. Zdrav Var 46, 85-90. 
11. Artnik B, Drev A, Drglin Z et al. (2011) Neenakosti v zdravju in $z$ zdravjem povezanih vedenjih slovenskih mladostnikov. Ljubljana: Inštitut za varovanje zdravja RS.

12. Fidler Mis N, Kobe H \& Štimec M (2012) Dietary intake of macro- and micronutrients in Slovenian adolescents: comparison with reference values. Ann Nutr Metab 61, 305-313.

13. World Health Organization (2006) Food and Nutrition Policy for Schools. Copenhagen: WHO Regional Office for Europe.

14. Condon ES, Crepinsek MK \& Fox MK (2009) School meals: types of food offered to and consumed by children at lunch and breakfast. J Am Diet Assoc 109, 67-78.

15. Adamson A, Spence S, Reed L et al. (2013) School food standards in the UK: implementation and evaluation. Public Health Nutr 16, 968-981.

16. Jacoby HG (2002) Is there an intrahousehold 'flypaper effect? Evidence from a school feeding programme. Econ J 112, 196-221.

17. Afridi F (2005) The Impact of Public Transfers on Intrahousehold Resource Allocation: Evidence from a Supplementary School Feeding Program. Ann Arbor, MI: University of Michigan; available at http://paa2005.princeton.edu/ papers $/ 50075$

18. Alaimo K, Olsžon CM, Frongillo EA et al. (2001) Food insufficiency, family income, and health in US preschool and school-aged children. J Am Public Health Assoc 91, 781-786.

19. St-Onge M, Keller K \& Heymsfield S (2003) Changes in childhood food consumption patterns: a cause for concern in light of increasing body weights. Am J Clin Nutr $\mathbf{7 8}$, 1068-1073.

20. Uradni list RS (2010) Zakon o šolski prehrani (ZŠolPre). Ljubljana: Uradni list 43; available at https://www.uradnilist.si/1/content?id=98032

21. Gabrijelčič Blenkuš M, Pograjc L, Gregorič M et al. (2005) Smernice zdravega prehranjevanja v vzgojno izobraževalnib ustanovah: od prvega leta starosti naprej (National Dietary Guidelines for Healthy Nutrition in Kindergartens and Schools). Ljubljana: Ministrstvo za zdravje RS.

22. Maučec Zakotnik J, Hlastan Ribič C, Poličnik R et al. (2005) The National Programme of Food and Nutrition Policy 2005-2010. Ljubljana: Ministry of Health of the Republic of Slovenia.

23. Story M, Kaphingst KM, Robinson-O'Brien R et al. (2008) Creating healthy food and eating environments: policy and environmental approaches. Annu Rev Public Health 29 , 253-272.

24. Lock K \& Jaime PC (2009) Do school based food and nutrition policies improve diet and reduce obesity? Prev Med 48, 45-53.

25. Cauwenberghe E, Maes L, Spittaels H et al. (2010) Effectiveness of school-based interventions in Europe to promote healthy nutrition in children and adolescents: systematic review of published and 'grey' literature. Br J Nutr $\mathbf{1 0 3}$, 781-797.

26. Nutbeam D \& Bauman AE (2006) Evaluation in a Nutshell: A Practical Guide to the Evaluation of Health Promotion Programs. Sydney: McGraw-Hill.

27. Norman G (2010) Likert scales levels of measurement and the 'laws' of statistics. Adv Health Sci Educ Theory Pract 15, 625-632.

28. Willcoxson L \& Millett B (2000) The management of organisational culture. Aust J Manage Organ Behav 3, 91-99.

29. Hlastan Ribič C, Maučec Zakotnik J, Koroušić Seljak B et al. (2008) Praktikum jedilnikov zdravega prehranjevanja $v$ vzgojno-izobraževalnih ustanovah (od prvega leta starosti naprej). Ljubljana: Ministrstvo za zdravje RS \& Zavod RS za šolstvo.

30. Pograjc L, Poličnik R \& Hlastan Ribič C (2008) Priročnik z merili kakovosti za živila v vzgojno-izobraževalnib ustanovah. Ljubljana: Ministrstvo za zdravje RS.
31. Gregorič M, Gabrijelčič Blenkuš M, Klančar K et al. (2010) Vrednotenje osnounošolske prehrane glede ponudbe, načina planiranja in organiziranosti $v$ letu 2010. Ljubljana: Inštitut za varovanje zdravja RS; available at http://www.ivz.si/publikacije?pi=3\&_3_Filename=3697. pdf\&_3_MediaId=3697\&_3_AutoResize=false $\& p l=109-3.3$

32. Rok Simon M, Bajt M, Brcar P et al. (2010) Zdravje otrok in mladostnikov. In Zdravje $v$ Sloveniji, pp. 50-54 [J Trdič, M Gabrijelčič Blenkuš, T Kofol Bric et al., editors]. Ljubljana: Inštitut za varovanje zdravja RS.

33. Buzeti T, Djomba JK, Gabrijelčič Blenkuš M et al. (2011) Health inequalities in Slovenia. Ljubljana: National Institute of Public Health.

34. Gabrijelčič Blenkuš M (2001) Daily meal frequency of secondary school students from Ljubljana in relation to some of their other nutritional and life-style characteristics and body mass index - preliminary results. Zdrav Vestn 70, 269-274.

35. Kleiser C, Mensink GBM, Scheidt-Nave C et al. (2009) HuSKY: a healthy nutrition score based on food intake of children and adolescents in Germany. Br J Nutr 102, 610-618.

36. Kennedy ET, Ohls J, Carlson S et al. (1995) The Healthy Eating Index: design and applications. J Am Diet Assoc 95 , 1103-1108.

37. Thiele S, Mensink GBM \& Beitz R (2004) Determinants of diet quality. Public Health Nutr 7, 29-37.

38. Waijers PMCM, Feskens EJM \& Ocké MC (2002) A critical review of predefined diet quality scores. Br J Nutr 97, 219-231.

39. Lazarou C \& Newby PK (2011) Use of dietary indexes among children in developed countries. Adv Nutr 2, 295-303.

40. World Health Organization (2003) Diet, Nutrition and the Prevention of Chronic Diseases. Joint WHO/FAO Expert Consultation. WHO Technical Report Series no. 916. Geneva: WHO.

41. German Nutrition Society, Austrian Nutrition Society, Swiss Society for Nutrition Research et al. (2004) Referenčne vrednosti za vnos branil (Reference Values for Nutrient Intake), 1st ed. Ljubljana: Ministrstvo za zdravje RS.

42. Willett WC (2012) Nutritional Epidemiology. New York: Oxford University Press.

43. Bingham SA, Welch AA, McTaggart A et al. (2001) Nutritional methods in the European Prospective Investigation of Cancer in Norfolk. Public Health Nutr 4, 847-858.

44. Livingstone MB, Prentice AM, Strain JJ et al. (1999) Accuracy of weighed dietary records in studies of diet and health. BMJ 300, 708-712.

45. Gregorič M, Gabrijelčič Blenkuš M, Ceglar K et al. (2012) Vrednotenje kosil osnounošolske prehrane v letu 2011 na podlagi izbranega vzorca šol. Ljubljana: Inštitut za varovanje zdravja RS; available at http://img.ivz.si/janez/2060-5516.pdf

46. Koroušić Seljak B (2010) Web-based eHealth applications with reference to food composition data. Eur J Clin Nutr $\mathbf{6 4}$, 121-127.

47. Kasenburger P (2005) Prehranjevalne navade in ocena hranilnih vrednosti toplih malic $\mathrm{v}$ podjetjih $\mathrm{z}$ organizirano prehrano. Magistrsko delo. Ljubljana: Univerza v Ljubljani, Biotehniška fakulteta.

48. SPSS, Inc. (2005) SPSS 14.0 Base User's Guide. Chicago, IL: SPSS, Inc.

49. Kostanjevec S, Jerman J \& Koch V (2012) The influence of nutrition education on the food consumption and nutrition attitude of schoolchildren in Slovenia. US-China Educ Rev 11, 953-964.

50. Kafatos A, Manios Y \& Moschandreas J (2005) Health and nutrition education in primary schools of Crete: follow-up changes in body mass index and overweight status. Eur J Clin Nutr 59, 1090-1092.

51. Powers AR, Struempler BJ, Guarino A et al. (2005) Effects of a nutrition education program on the dietary behavior and nutrition knowledge of second-grade and third-grade students. J Sch Health 75, 129-133. 
52. Cullen KW, Hartstein J, Reynolds KD et al. (2007) Improving the school food environment: results from a pilot study in middle schools. J Am Diet Assoc 107, 484-489.

53. Lien N (2012) Does the school food environment influence the dietary behaviours of Norwegian 11-year-olds? The HEIA study. Scand J Public Health 40, 491-497.

54. Matthews A, Nelson M, Kaur A et al. (2011) Where has all the chocolate gone? A national survey assesses the effects of recent legislation to improve the nutritional quality of English secondary-school vending. Public Health Nutr 14, 1394-1402.

55. Moore L, Moore GF, Tapper K et al. (2007) Free breakfasts in schools: design and conduct of a cluster randomised controlled trial of the Primary School Free breakfast Initiative in Wales. BMC Public Health 7, 258.

56. Shemilt I, Harvey I, Shepstone L et al. (2004) A national evaluation of school breakfast clubs: evidence from a cluster randomised controlled trial and an observational analysis. Child Care Health Dev 30, 413-427.

57. Ozer EJ (2007) The effects of school gardens on students and schools: conceptualization and considerations for maximizing healthy development. Health Educ Behav 34, 846-863.

58. de Sa J \& Lock K (2008) Will European agricultural policy for school fruit and vegetables improve public health? A review of school fruit and vegetable programmes. Eur $J$ Public Health 18, 558-568.

59. Wells L \& Nelson M (2005) The National School Fruit Scheme produces short-term but not longer-term increases in fruit consumption in primary school children. BrJ Nutr 93, $537-542$.

60. Lesnik T, Gabrijelčič Blenkuš M, Gregorič M et al. (2011) School Fruit Scheme Evaluation Report for the 2010/2011 School Year. Ljubljana: National Institute of Public Health of the Republic of Slovenia; available at http://ec.europa.eu/ agriculture/sfs/documents/si_summary_evaluation_report_-2010-2011_en.pdf

61. French SA, Story M, Fulkerson JA et al. (2004) An environmental intervention to promote lower-fat food choices in secondary schools: outcomes of the TACOS Study. Am J Public Health 94, 1507-1512.

62. Blum JE, Davee AM, Beaudoin CM et al. (2008) Reduced availability of sugar-sweetened beverages and diet soda has a limited impact on beverage consumption patterns in Maine high school youth. J Nutr Educ Behav 40, 341-347.
63. Cullen KW, Watson K \& Zakeri I (2008) Improvements in middle school student dietary intake after implementation of the Texas Public School Nutrition Policy. Am J Public Health 98, 111-117.

64. Dick M, Lee A, Bright M et al. (2012) Evaluation of implementation of a healthy food and drink supply strategy throughout the whole school environment in Queensland state schools, Australia. Eur J Clin Nutr 66, 1124-1129.

65. Simčič I (2007) Organizacija šolske prehrane in oblikovanje cen prehranskih obrokov v vzgojnoizobraževalnih ustanovah. Ljubljana: Ministrstvo za zdravje RS.

66. Chambers S, Lobb A, Butler L et al. (2007) Local, national and imported foods: a qualitative study. Appetite $\mathbf{4 9}$, 208-213.

67. Hu FB (2002) Dietary pattern analysis: a new direction in nutritional epidemiology. Curr Opin Lipidol 13, 3-9.

68. Poklar Vatovec T (2008) Oblikovanje večkriterijskega modela za vrednotenje šolske prehrane $\mathrm{v}$ Sloveniji. Doktorska disertacija, Univerza v Ljubljani.

69. Kral TV \& Rolls BJ (2004) Energy density and portion size: their independent and combined effects on energy intake. Physiol Behav 82, 131-138.

70. Salamoun MM, Kizirian AS, Tannous RI et al. (2005) Low calcium and vitamin D intake in healthy children and adolescents and their correlates. Eur J Clin Nutr 59, 177-184.

71. Serra-Majem L (2001) Vitamin and mineral intakes in European children. Is food fortification needed? Public Health Nutr 4, 101-107.

72. Gould R, Russell J \& Barker ME (2006) School lunch menus and 11 to 12 year old children's food choice in three secondary schools in England - are the nutritional standards being met? Appetite 46, 86-92.

73. Lambert J, Agostoni C, Elmadfa I et al. (2004) Dietary intake and nutritional status of children and adolescents in Europe. Br J Nutr 92, 147-211.

74. Oxman AD, Bjorndal A, Bacerra-Posada F et al. (2010) A framework for mandatory impact evaluation to ensure well informed public policy decisions. Lancet 375, 427-431.

75. Leppo K, Ollila E, Pena S et al., (editors) (2013) Health in all Policies. Seizing Opportunities, Implementing Policies. Helsinki: Ministry of Social Affairs and Health.

76. van Kammen J, de Savigny D \& Sewankambo N (2006) Using knowledge brokering to promote evidence based policy-making: the need for support structures. Bull World Health Organ 84, 608-612. 